cillamine (E. L. Smith, personal communication), which has already been shown to be capable of increasing the growth-rate of chicks when given by daily injection. Further work is being undertaken elsewhere to evaluate the nutritional significance of this material.

We are grateful to Dr. R. C. Campbell for statistical analysis of the experimental results, to Mr. R. Long of Glaxo Laboratories, Ltd., for preparation of the inactivated penicillin, and to Glaxo Laboratories, Ltd., for supplying the penicillin used in these experiments.

\section{J. H. TAYLOR}

W. S. GORDON

Agricultural Research Council

Field Station,

Compton, Berkshire. April 4.

${ }^{1}$ Jukes, T. H., and Williams, W. L., Pharmacol. Rev., 5, 381 (1953). - Elam, Gee and Couch, Proc. Soc. Exp. Biol., N.Y., 8, 832 (1951).

${ }^{8}$ Ministry of Agriculture Advisory Leaflet No. 104, Pig Feeding, p. 2 (H.M.S.O., London, 1953).

- Fell and Stephenson, Poultry Sci., 32, 1092 (1953).

\section{A New Rare Blood-Group Antigen, Chro}

During recent years, many rare blood-group antigens, co-called 'private' or 'family' antigens, have been discovered. A survey of eleven of these was recently made by van Loghem and his associates, who described two new antigens. Most of the antigens were found exclusively in the members of one family; but as suggested by Dunsford, who studied the Wright system, some of these antigens may be ordinary blood-group factors with a very low frequency. Most of the corresponding antibodies were the results of iso-immunization during pregnancy or by blood transfusion, but a few of them were naturally occurring antibodies.

Through routine screening for blood-group antibodies we found a hitherto unknown antibody, which at $37^{\circ} \mathrm{C}$. agglutinated trypsinized red cells from one of the test-cell donors, who happened to be the present writer. The serum donor was a nineteen-year-old unmarried woman, who had never received transfusions and had never been pregnant. Serological investigations showed that the antibody was most active in albumin at $37^{\circ}$ (titre 8 ). It was less active in seline and by the trypsin technique, and it gave no reaction by the indirect Coombs technique. The antibody was weakly active at $20^{\circ}$. The test serum has since been tested against the red cells from 311 persons selected at random; but so far it has been found to react with the red cells from only one more person.

Investigations of the blood-group genotypes of the test-serum donor and of the two persons whose red cells had reacted with the test serum gave the following results :

B. Chr. (test-serum donor): $A$, ODe/c e, $M N s$, $L e(a+), P, k / k$.

F. K.-N.: $O$ cde/cde, $M N s, L e(a-), P, k / k$, $L u(a-), F y(a-), J k(a+)$.

S. S. : $O$ cde/cde, $M N s, K, L e(a-), p / p$.

Studies of the families of F. K.-N. and S. S. have not revealed other persons giving positive reactions with the test serum; but unfortunately it has been impossible to draw any conclusions concerning inheritance from the results obtained in the available family material. Seven relatives of F. K.-N., including two brothers, one sister and the mother, and three relatives of S. S., two brothers and one sister, have been investigated.

The test serum has been investigated by Miss Mia van der Hart and Dr. J. J. van Loghem, who found that the antibody was different from antibodies reacting with the following 'private' blood-group antigens : $V w$ (Verweyst), $R m$ (Romunde) and $V$ is (Wright). Testing against 150 blood samples chosen at random gave negative results. The test serum was also investigated by Dr. A. E. Mourant, of the Lister Institute, London. He stated that the antiserum was not identical with those from Berrens, Graydon, Wright and two other 'family' antisera which are as yet unpublished. Dr. E. Freiesleben has tested the serum against thirty-nine random blood samples, also with negative results. Thus, including my own investigations, the serum has been tested against a total of five hundred random blood samples, of which only two gave positive reactions, which gives a frequency of 0.4 per cent. The antibody has been named anti$\mathrm{Chr}^{\mathrm{a}}$ on the supposition that an anti-Chib reacting with a very common blood-group antigen may exist.

I wish to thank Dr. A. E. Mourant and Dr. Dorothy M. Parkin, of the Lister Institute, London, Miss Mia van der Hart and Dr. J. J. van Loghem, Amsterdam, and Dr. E. Freiesleben, of Statens Seruminstitut, Copenhagen, who all assisted me in the serological investigations.

This work was aided by grants from the Anders Hasselbalch Anti-Leukæmiø Foundation and C. P. Schepler and Wife's Bequest, the Irma Foundation.

\section{F. KISSMEYER-NIELSEN *}

Institute of General Pathology,

University of Aarhus. March 26.

* Lady Tata Memorial Scholar.

1 Dunsford, J., Vox Sang., 4, 160 (1954).

san der Hart, M., Bosman, H., and van Loghem, J. J., Vox Sang., 4, 108 (1954).

\section{Some Notably High Acuities of Taste for Phenylthiocarbamide}

IN the course of a recent study of the thresholds of taste for phenylthiocarbamide (phenylthiourea) of members of a division of the Malayan Negritos, some extraordinarily high acuities were encountered.

The Negritos under study belonged to the Kintak Bong division, most of the few remaining members of which are at present living in the Baling district of the State of Kedah, Federation of Malaya. They are probably the 'purest' of the Negritos still living in the Malay Peninsula. The phenylthiocarbamide solutions employed in the work comprised a series numbered $0,1,2, \ldots 18$, the concentration of the substance being $2 \cdot 60 \times 2^{-n} \mathrm{gm}$. per litre, where $n$ is the solution number.

Three of the youths, aged seventeen, eighteen and fifteen years, were able successfully to distinguish in sorting trials between the solvent (distilled water) and solutions numbered 18, 17 and 16, respectively, the chance of success by guesswork being 0.125 in each case. Assuming that guesswork actually played 